\title{
Histamine receptors in GtoPdb v.2021.3
}

Paul Chazot ${ }^{1}$, Marlon Cowart ${ }^{2}$, Hiroyuki Fukui ${ }^{3}$, C. Robin Ganellin ${ }^{4}$, Ralf Gutzmer ${ }^{5}$, Helmut L. Haas ${ }^{6}$, Stephen J. Hill ${ }^{7}$, Rebecca Hills ${ }^{8}$, Rob Leurs ${ }^{9}$, Roberto Levi ${ }^{10}$, Steve Liu ${ }^{11}$, Pertti Panula ${ }^{12}$, Walter Schunack $^{13}$, Jean-Charles Schwartz ${ }^{14}$, Roland Seifert ${ }^{15}$, Nigel P. Shankley ${ }^{16}$, Holger Stark ${ }^{17}$, Robin Thurmond ${ }^{16}$, Henk Timmerman ${ }^{9}$ and J. Michael Young ${ }^{18}$

1. Durham University, UK

2. Abbott Laboratories, USA

3. University of Tokushima, Japan

4. University College London, UK

5. Hannover Medical School, Germany

6. Heinrich Heine University, Germany

7. University of Nottingham, UK

8. University of Edinburgh, UK

9. Vrije Universiteit Amsterdam, The Netherlands

10. Cornell University, USA

11. Pfizer, UK

12. University of Helsinki, Finland

13. Freie Universitat Berlin, Germany

14. INSERM, France

15. Medical School of Hannover, Germany

16. Johnson \& Johnson Pharmaceutical Research \& Development, USA

17. Goethe University, Germany

18. University of Cambridge, UK

\begin{abstract}
Histamine receptors (nomenclature as agreed by the NC-IUPHAR Subcommittee on

Histamine Receptors [80, 173]) are activated by the endogenous ligand histamine. Marked species differences exist between histamine receptor orthologues [80]. The human and rat $\mathrm{H}_{3}$ receptor genes are subject to significant splice variance [12]. The potency order of histamine at histamine receptor subtypes is $\mathrm{H}_{3}=\mathrm{H}_{4}>\mathrm{H}_{2}>\mathrm{H}_{1}$ [173]. Some agonists at the human $\mathrm{H}_{3}$ receptor display significant ligand bias [182]. Antagonists of all 4 histamine receptors have clinical uses: $\mathrm{H}_{1}$ antagonists for allergies (e.g. cetirizine), $\mathrm{H}_{2}$ antagonists for acid-reflux diseases (e.g. ranitidine), $\mathrm{H}_{3}$ antagonists for narcolepsy (e.g. pitolisant/WAKIX; Registered) and $\mathrm{H}_{4}$ antagonists for atopic dermatitis (e.g. adriforant; Phase IIa) [173] and vestibular neuritis (AUV) (SENS-111 (Seliforant, previously UR-63325), entered and completed vestibular neuritis (AUV) Phase IIa efficacy and safety trials, respectively) $[216,8]$.
\end{abstract}

\section{Contents}

This is a citation summary for Histamine receptors in the Guide to Pharmacology database (GtoPdb). It exists purely as an adjunct to the database to facilitate the recognition of citations to and from the database by citation analyzers. Readers will almost certainly want to visit the relevant sections of the database which are given here under database links.

GtoPdb is an expert-driven guide to pharmacological targets and the substances that act on them. GtoPdb is a reference work which is most usefully represented as an on-line database. As in any publication this work should be appropriately cited, and the papers it cites should also be recognized. This document provides a citation for the relevant parts of the database, and also provides a reference list for the research cited by those parts. For further details see [26].

Please note that the database version for the citations given in GtoPdb are to the most recent preceding version in which the family or its subfamilies and targets were substantially changed. The 
links below are to the current version. If you need to consult the cited version, rather than the most recent version, please contact the GtoPdb curators.

\section{Database links}

Histamine receptors

https://www.guidetopharmacology.org/GRAC/FamilyDisplayForward?familyId=33

Introduction to Histamine receptors

https://www.guidetopharmacology.org/GRAC/FamilyIntroductionForward?familyId=33

Receptors

$\mathrm{H}_{1}$ receptor

https://www.guidetopharmacology.org/GRAC/ObjectDisplayForward?objectId=262

$\mathrm{H}_{2}$ receptor

https://www.guidetopharmacology.org/GRAC/ObjectDisplayForward?objectId=263

$\mathrm{H}_{3}$ receptor

https://www.guidetopharmacology.org/GRAC/ObjectDisplayForward?objectId=264

$\mathrm{H}_{4}$ receptor

https://www.guidetopharmacology.org/GRAC/ObjectDisplayForward?objectId=265

\section{References}

1. Alewijnse AE, Smit MJ, Hoffmann M, Verzijl D, Timmerman H and Leurs R. (1998) Constitutive activity and structural instability of the wild-type human H2 receptor. J Neurochem 71: 799-807 [PMID:9681472]

2. Alvarez EO and Banzán AM. (1986) Histamine in dorsal and ventral hippocampus. II. Effects of $\mathrm{H} 1$ and $\mathrm{H} 2$ histamine antagonists on exploratory behavior in male rats. Physiol Behav 37: 39-45 [PMID:3016772]

3. Apodaca R, Dvorak CA, Xiao W, Barbier AJ, Boggs JD, Wilson SJ, Lovenberg TW and Carruthers NI. (2003) A new class of diamine-based human histamine H3 receptor antagonists: 4(aminoalkoxy)benzylamines. J Med Chem 46: 3938-44 [PMID:12930154]

4. Arrang JM, Garbarg M, Lancelot JC, Lecomte JM, Pollard H, Robba M, Schunack W and Schwartz JC. (1987) Highly potent and selective ligands for histamine H3-receptors. Nature 327: 117-23 [PMID:3033516]

5. Arrang JM, Garbarg M and Schwartz JC. (1983) Auto-inhibition of brain histamine release mediated by a novel class (H3) of histamine receptor. Nature 302: 832-7 [PMID:6188956]

6. ARUNLAKSHANA O and SCHILD HO. (1959) Some quantitative uses of drug antagonists. $\mathrm{Br} \mathrm{J}$ Pharmacol Chemother 14: 48-58 [PMID:13651579]

7. Aslanian R, Piwinski JJ, Zhu X, Priestley T, Sorota S, Du XY, Zhang XS, McLeod RL, West RE and Williams SM et al.. (2009) Structural determinants for histamine H(1) affinity, hERG affinity and QTc prolongation in a series of terfenadine analogs. Bioorg Med Chem Lett 19: 5043-7 [PMID:19660947]

8. Attali P, Gomeni R, Wersinger E, Poli S and Venail F. (2016) The Effects of SENS-111, A New H4R Antagonist, On Vertigo Induced by Caloric Test in Healthy Volunteers (HV) is Related to Plasma Concentrations. Clin Ther 38: e4 [PMID:27673668]

9. Auerbach SS and DrugMatrix ${ }^{\circledR}$ and ToxFX ${ }^{\circledR}$ Coordinator National Toxicology Program.. National Toxicology Program: Dept of Health and Human Services.

10. Azuma H, Sawada S, Takeuchi S, Higashiyama K, Kakigi A and Takeda T. (2003) Expression of mRNA encoding the $\mathrm{H} 1, \mathrm{H} 2$, and $\mathrm{H} 3$ histamine receptors in the rat cochlea. Neuroreport 14: 423-5 [PMID:12634496]

11. Bahl A, Barton P, Bowers K, Brough S, Evans R, Luckhurst CA, Mochel T, Perry MW, Rigby A and Riley RJ et al.. (2012) The discovery of CCR3/H1 dual antagonists with reduced hERG risk. Bioorg Med Chem Lett 22: 6688-93 [PMID:23031591]

12. Bakker RA, Lozada AF, van Marle A, Shenton FC, Drutel G, Karlstedt K, Hoffmann M, Lintunen M, Yamamoto Y and van Rijn RM et al.. (2006) Discovery of naturally occurring splice variants of the rat histamine H3 receptor that act as dominant-negative isoforms. Mol Pharmacol 69: 1194206 [PMID:16415177]

13. Barocelli E, Ballabeni V, Chiavarini M and Impicciatore M. (1995) R-alpha-methylhistamineinduced inhibition of gastric acid secretion in pylorus-ligated rats via central histamine $\mathrm{H} 3$ receptors. Br J Pharmacol 115: 1326-30 [PMID:7582564]

14. Benavides J, Schoemaker H, Dana C, Claustre Y, Delahaye M, Prouteau M, Manoury P, Allen J, Scatton B and Langer SZ et al.. (1995) In vivo and in vitro interaction of the novel selective histamine $\mathrm{H} 1$ receptor antagonist mizolastine with $\mathrm{H} 1$ receptors in the rodent. Arzneimittelforschung 45: 551-8 [PMID:7612054]

15. Berlin M, Boyce CW and Ruiz Mde L. (2011) Histamine H3 receptor as a drug discovery target. J Med Chem 54: 26-53 [PMID:21062081] 
16. Beukers MW, Klaassen CH, De Grip WJ, Verzijl D, Timmerman H and Leurs R. (1997) Heterologous expression of rat epitope-tagged histamine $\mathrm{H} 2$ receptors in insect Sf9 cells. $\mathrm{Br} J$ Pharmacol 122: 867-74 [PMID:9384502]

17. Bhargava KP, Nath R and Palit G. (1977) Nature of histamine receptors concerned in capillary permeability. Br J Pharmacol 59: 349-351 [PMID:837022]

18. Black J. (1989) Nobel lecture in physiology or medicine--1988. Drugs from emasculated hormones: the principle of syntopic antagonism. In Vitro Cell Dev Biol 25: 311-20 [PMID:2565896]

19. Black JW, Duncan WA, Durant CJ, Ganellin CR and Parsons EM. (1972) Definition and antagonism of histamine H 2 -receptors. Nature 236: 385-90 [PMID:4401751]

20. Booth RG, Moniri NH, Bakker RA, Choksi NY, Nix WB, Timmerman H and Leurs R. (2002) A novel phenylaminotetralin radioligand reveals a subpopulation of histamine $\mathrm{H}(1)$ receptors. $J$ Pharmacol Exp Ther 302: 328-36 [PMID:12065734]

21. Borda E, Stranieri G and Sterin-Borda L. (2002) H(1)-Receptor activation triggers the endogenous nitric oxide signalling system in the rat submandibular gland. Mediators Inflamm 11: 337-343 [PMID:12581497]

22. Borella LE and Lippmann W. (1978) A relatively specific and quantitative assay for histamine H2-receptor blocking activity by determination of inhibition of histamine-induced gastric acid secretion in the rat. Eur J Pharmacol 52: 153-9 [PMID:32047]

23. Brimblecombe RW, Duncan WA, Durant GJ, Emmett JC, Ganellin CR, Leslie GB and Parsons ME. (1978) Characterization and development of cimetidine as a histamine H2-receptor antagonist. Gastroenterology 74: 339-47 [PMID:23336]

24. Brown RE and Haas HL. (1999) On the mechanism of histaminergic inhibition of glutamate release in the rat dentate gyrus. J Physiol (Lond.) 515 ( Pt 3): 777-86 [PMID:10066904]

25. Buckland KF, Williams TJ and Conroy DM. (2003) Histamine induces cytoskeletal changes in human eosinophils via the $\mathrm{H}(4)$ receptor. Br J Pharmacol 140: 1117-27 [PMID:14530216]

26. Buneman P, Christie G, Davies JA, Dimitrellou R, Harding SD, Pawson AJ, Sharman JL and Wu Y. (2020) Why data citation isn't working, and what to do about it Database 2020 [PMID:32367113]

27. Bárbara A, Aceves J and Arias-Montaño JA. (2002) Histamine H1 receptors in rat dorsal raphe nucleus: pharmacological characterisation and linking to increased neuronal activity. Brain Res 954: 247-55 [PMID:12414108]

28. Böhme TM, Keim C, Kreutzmann K, Linder M, Dingermann T, Dannhardt G, Mutschler E and Lambrecht G. (2003) Structure-activity relationships of dimethindene derivatives as new M2selective muscarinic receptor antagonists. J Med Chem 46: 856-67 [PMID:12593665]

29. Cangioli I, Baldi E, Mannaioni PF, Bucherelli C, Blandina P and Passani MB. (2002) Activation of histaminergic $\mathrm{H} 3$ receptors in the rat basolateral amygdala improves expression of fear memory and enhances acetylcholine release. Eur J Neurosci 16: 521-8 [PMID:12193196]

30. Cannon KE, Chazot PL, Hann V, Shenton F, Hough LB and Rice FL. (2007) Immunohistochemical localization of histamine H3 receptors in rodent skin, dorsal root ganglia, superior cervical ganglia, and spinal cord: potential antinociceptive targets. Pain 129: 76-92 [PMID:17134835]

31. Cannon KE and Hough LB. (2005) Inhibition of chemical and low-intensity mechanical nociception by activation of histamine H3 receptors. J Pain 6: 193-200 [PMID:15772913]

32. Cannon KE, Nalwalk JW, Stadel R, Ge P, Lawson D, Silos-Santiago I and Hough LB. (2003) Activation of spinal histamine H3 receptors inhibits mechanical nociception. EurJ Pharmacol 470: 139-47 [PMID:12798951]

33. Cappelli A, Manini M, Valenti S, Castriconi F, Giuliani G, Anzini M, Brogi S, Butini S, Gemma S and Campiani G et al.. (2013) Synthesis and structure-activity relationship studies in serotonin 5-HT1A receptor agonists based on fused pyrrolidone scaffolds. Eur J Med Chem 63: 85-94 [PMID:23466604]

34. Casterline CL and Evans R. (1977) Further studies on the mechanism of human histamineinduced asthma: the effect of an aerosolized H1 receptor antagonist (diphenhydramine). $J$ Allergy Clin Immunol 59: 420-4 [PMID:16944]

35. Chazot PL, Hann V, Wilson C, Lees G and Thompson CL. (2001) Immunological identification of the mammalian H3 histamine receptor in the mouse brain. Neuroreport 12: 259-62 [PMID:11209931]

36. Chen J, Liu C and Lovenberg TW. (2003) Molecular and pharmacological characterization of the mouse histamine H3 receptor. Eur J Pharmacol 467: 57-65 [PMID:12706455]

37. Clark EA and Hill SJ. (1996) Sensitivity of histamine H3 receptor agonist-stimulated [35S]GTP gamma[S] binding to pertussis toxin. Eur J Pharmacol 296: 223-5 [PMID:8838460]

38. Clark MA, Korte A and Egan RW. (1993) Guanine nucleotides and pertussis toxin reduce the affinity of histamine H3 receptors on AtT-20 cells. Agents Actions 40: 129-34 [PMID:8023737]

39. Cogé F, Guénin SP, Audinot V, Renouard-Try A, Beauverger P, Macia C, Ouvry C, Nagel N, Rique $\mathrm{H}$ and Boutin JA et al.. (2001) Genomic organization and characterization of splice 
variants of the human histamine H3 receptor. Biochem J 355: 279-88 [PMID:11284713]

40. Cogé F, Guénin SP, Rique H, Boutin JA and Galizzi JP. (2001) Structure and expression of the human histamine H4-receptor gene. Biochem Biophys Res Commun 284: 301-9 [PMID:11394877]

41. Coon T, Moree WJ, Li B, Yu J, Zamani-Kord S, Malany S, Santos MA, Hernandez LM, Petroski RE and Sun A et al.. (2009) Brain-penetrating 2-aminobenzimidazole H(1)-antihistamines for the treatment of insomnia. Bioorg Med Chem Lett 19: 4380-4 [PMID:19553115]

42. Corcóstegui R, Labeaga L, Innerárity A, Berisa A and Orjales A. (2005) Preclinical pharmacology of bilastine, a new selective histamine $\mathrm{H} 1$ receptor antagonist: receptor selectivity and in vitro antihistaminic activity. Drugs $R$ D 6: 371-84 [PMID:16274260]

43. Crimi N, Polosa R, Magrì S, Prosperini G, Paolino G, Mastruzzo C and Mistretta A. (1996) Inhaled lysine acetylsalicylate (L-ASA) attenuates histamine-induced bronchoconstriction in asthma. Allergy 51: 157-63 [PMID:8781669]

44. Dai H, Okuda T, Sakurai E, Kuramasu A, Kato M, Jia F, Xu AJ, Iinuma K, Sato I and Yanai K. (2005) Blockage of histamine H1 receptor attenuates social isolation-induced disruption of prepulse inhibition: a study in $\mathrm{H} 1$ receptor gene knockout mice. Psychopharmacology (Berl.) 183: 285-93 [PMID:16237577]

45. Daneshmand MA, Keller RS, Canver MC, Canver AC and Canver CC. (2004) Histamine H1 and $\mathrm{H} 2$ receptor-mediated vasoreactivity of human internal thoracic and radial arteries. Surgery 136: 458-63 [PMID:15300215]

46. De Backer MD, Gommeren W, Moereels H, Nobels G, Van Gompel P, Leysen JE and Luyten WH. (1993) Genomic cloning, heterologous expression and pharmacological characterization of a human histamine H1 receptor. Biochem Biophys Res Commun 197: 1601-8 [PMID:8280179]

47. De Backer MD, Loonen I, Verhasselt P, Neefs JM and Luyten WH. (1998) Structure of the human histamine H1 receptor gene. Biochem J 335 ( Pt 3): 663-70 [PMID:9794809]

48. de Esch IJ, Thurmond RL, Jongejan A and Leurs R. (2005) The histamine H4 receptor as a new therapeutic target for inflammation. Trends Pharmacol Sci 26: 462-9 [PMID:16054239]

49. Dijkstra D, Leurs R, Chazot P, Shenton FC, Stark H, Werfel T and Gutzmer R. (2007) Histamine downregulates monocyte CCL2 production through the histamine H4 receptor. J Allergy Clin Immunol 120: 300-7 [PMID:17507084]

50. Drutel G, Peitsaro N, Karlstedt K, Wieland K, Smit MJ, Timmerman H, Panula P and Leurs R. (2001) Identification of rat $\mathrm{H} 3$ receptor isoforms with different brain expression and signaling properties. Mol Pharmacol 59: 1-8 [PMID:11125017]

51. Edwards JP, Kindrachuk DE, Venable JD, Mapes CM, Pippel DJ and . (2007) Benzoimidazol-2-yl pyrimidines and pyrazines as modulators of the histamine $\mathrm{H} 4$ receptor Patent number: WO2007117399.

52. Eiser NM, Mills J, Snashall PD and Guz A. (1981) The role of histamine receptors in asthma. Clin Sci (Lond.) 60: 363-370 [PMID:7249528]

53. Endou M, Poli E and Levi R. (1994) Histamine H3-receptor signaling in the heart: possible involvement of Gi/Go proteins and N-type Ca++ channels. J Pharmacol Exp Ther 269: 221-9 [PMID:8169830]

54. Ercan ZS and Türker RK. (1977) Histamine receptors in the isolated rat stomach fundus and rabbit aortic strips. Pharmacology 15: 118-26 [PMID:847009]

55. Esbenshade TA, Fox GB, Krueger KM, Baranowski JL, Miller TR, Kang CH, Denny LI, Witte DG, Yao BB and Pan JB et al.. (2004) Pharmacological and behavioral properties of A-349821, a selective and potent human histamine H3 receptor antagonist. Biochem Pharmacol 68: 933-45 [PMID:15294456]

56. Esbenshade TA, Fox GB, Krueger KM, Miller TR, Kang CH, Denny LI, Witte DG, Yao BB, Pan L and Wetter J et al.. (2005) Pharmacological properties of ABT-239 [4-(2-\{2-[(2R)-2-

Methylpyrrolidinyl]ethyl -benzofuran-5-yl)benzonitrile]: I. Potent and selective histamine H3 receptor antagonist with drug-like properties. J Pharmacol Exp Ther 313: 165-75 [PMID:15608078]

57. Esbenshade TA, Krueger KM, Miller TR, Kang CH, Denny LI, Witte DG, Yao BB, Fox GB, Faghih $\mathrm{R}$ and Bennani YL et al.. (2003) Two novel and selective nonimidazole histamine H3 receptor antagonists A-304121 and A-317920: I. In vitro pharmacological effects. J Pharmacol Exp Ther 305: 887-96 [PMID:12606603]

58. Fujimoto K, Horio Y, Sugama K, Ito S, Liu YQ and Fukui H. (1993) Genomic cloning of the rat histamine H1 receptor. Biochem Biophys Res Commun 190: 294-301 [PMID:7678492]

59. Fukagawa K, Sakata T, Shiraishi T, Yoshimatsu H, Fujimoto K, Ookuma K and Wada H. (1989) Neuronal histamine modulates feeding behavior through H1-receptor in rat hypothalamus. Am J Physiol 256: R605-R611 [PMID:2564258]

60. Fukui H, Fujimoto K, Mizuguchi H, Sakamoto K, Horio Y, Takai S, Yamada K and Ito S. (1994) Molecular cloning of the human histamine H1 receptor gene. Biochem Biophys Res Commun 201: 894-901 [PMID:8003029]

61. Fukushima Y, Otsuka H, Ishikawa M, Asano T, Anai M, Katsube T, Ogawa K, Kajiwara T, Ohkawa 
S and Ishikawa T et al.. (2001) Potent and long-lasting action of lafutidine on the human histamine H(2) receptor. Digestion 64: 155-60 [PMID:11786663]

62. Fung-Leung WP, Thurmond RL, Ling P and Karlsson L. (2004) Histamine H4 receptor antagonists: the new antihistamines? Curr Opin Investig Drugs 5: 1174-83 [PMID:15573868]

63. Gangwar RS, Landolina N, Arpinati L and Levi-Schaffer F. (2017) Mast cell and eosinophil surface receptors as targets for anti-allergic therapy. Pharmacol Ther 170: 37-63 [PMID:27773785]

64. Gantz I, Munzert G, Tashiro T, Schäffer M, Wang L, DelValle J and Yamada T. (1991) Molecular cloning of the human histamine H2 receptor. Biochem Biophys Res Commun 178: 1386-92 [PMID:1714721]

65. Gbahou F, Vincent L, Humbert-Claude M, Tardivel-Lacombe J, Chabret C and Arrang JM. (2006) Compared pharmacology of human histamine $\mathrm{H} 3$ and $\mathrm{H} 4$ receptors: structure-activity relationships of histamine derivatives. Br J Pharmacol 147: 744-54 [PMID:16432504]

66. Gespach C and Abita JP. (1982) Human polymorphonuclear neutrophils. Pharmacological characterization of histamine receptors mediating the elevation of cyclic AMP. Mol Pharmacol 21: 78-85 [PMID:6127623]

67. Gespach C, Saal F, Cost H and Abita JP. (1982) Identification and characterization of surface receptors for histamine in the human promyelocytic leukemia cell line HL-60. Comparison with human peripheral neutrophils. Mol Pharmacol 22: 547-53 [PMID:6185835]

68. Ghoneim OM, Legere JA, Golbraikh A, Tropsha A and Booth RG. (2006) Novel ligands for the human histamine $\mathrm{H} 1$ receptor: synthesis, pharmacology, and comparative molecular field analysis studies of 2-dimethylamino-5-(6)-phenyl-1,2,3,4-tetrahydronaphthalenes. Bioorg Med Chem 14: 6640-58 [PMID:16782354]

69. Gibbs BF and Levi-Schaffer F. (2012) $\mathrm{H}_{4}$ receptors in mast cells and basophils: a new therapeutic target for allergy? Front Biosci (Landmark Ed) 17: 430-7 [PMID:22201753]

70. Gillard M, Van Der Perren C, Moguilevsky N, Massingham R and Chatelain P. (2002) Binding characteristics of cetirizine and levocetirizine to human $\mathrm{H}(1)$ histamine receptors: contribution of Lys(191) and Thr(194). Mol Pharmacol 61: 391-9 [PMID:11809864]

71. Gonzalez R, Echeverria E, Reinicke K and Rudolph MI. (1994) Increased affinity of histamine H1 binding to membranes of human myometrium at the end of pregnancy. Gen Pharmacol 25: 1607-10 [PMID:7721035]

72. Gonzalez R, Reinicke K and Rudolph GM. (1993) Histamine H1 receptor binding sites in mouse uterine horns. Gen Pharmacol 24: 29-33 [PMID:8482504]

73. Govoni M, Bakker RA, van de Wetering I, Smit MJ, Menge WM, Timmerman H, Elz S, Schunack W and Leurs R. (2003) Synthesis and pharmacological identification of neutral histamine H1receptor antagonists. J Med Chem 46: 5812-24 [PMID:14667234]

74. Hancock AA, Bennani YL, Bush EN, Esbenshade TA, Faghih R, Fox GB, Jacobson P, KnourekSegel V, Krueger KM and Nuss ME et al.. (2004) Antiobesity effects of A-331440, a novel nonimidazole histamine H3 receptor antagonist. Eur J Pharmacol 487: 183-97 [PMID:15033391]

75. Hartwig C, Munder A, Glage S, Wedekind D, Schenk H, Seifert R and Neumann D. (2015) The histamine $\mathrm{H} 4$-receptor (H4 R) regulates eosinophilic inflammation in ovalbumin-induced experimental allergic asthma in mice. Eur J Immunol 45: 1129-40 [PMID:25501767]

76. Hauwert NJ, Mocking TAM, Da Costa Pereira D, Kooistra AJ, Wijnen LM, Vreeker GCM, Verweij EWE, De Boer AH, Smit MJ and De Graaf C et al.. (2018) Synthesis and Characterization of a Bidirectional Photoswitchable Antagonist Toolbox for Real-Time GPCR Photopharmacology. J Am Chem Soc 140: 4232-4243 [PMID:29470065]

77. Heinrich T, Böttcher H, Gericke R, Bartoszyk GD, Anzali S, Seyfried CA, Greiner HE and Van Amsterdam C. (2004) Synthesis and structure--activity relationship in a class of indolebutylpiperazines as dual 5-HT(1A) receptor agonists and serotonin reuptake inhibitors. $J$ Med Chem 47: 4684-92 [PMID:15341484]

78. Hernández-Angeles A, Soria-Jasso LE, Ortega A and Arias-Montaño JA. (2001) Histamine H1 receptor activation stimulates mitogenesis in human astrocytoma U373 MG cells. J Neurooncol 55: 81-9 [PMID:11817705]

79. Hill SJ. (1990) Distribution, properties and functional characteristics of three classes of histamine receptor. Pharmacol Rev 42: 45-83 [PMID:2164693]

80. Hill SJ, Ganellin CR, Timmerman H, Schwartz JC, Shankley NP, Young JM, Schunack W, Levi R and Haas HL. (1997) International Union of Pharmacology. XIII. Classification of histamine receptors. Pharmacol Rev 49: 253-78 [PMID:9311023]

81. Hino N, Marumo T, Kotani M, Shimazaki T, Kaku-Fukumoto A, Hikichi H, Karasawa JI, Tomishima Y, Komiyama H and Tatsuda E et al.. (2020) A Novel Potent and Selective Histamine $\mathrm{H}_{3}$ Receptor Antagonist Enerisant: In Vitro Profiles, In Vivo Receptor Occupancy, and WakePromoting and Procognitive Effects in Rodents. J Pharmacol Exp Ther 375: 276-285 [PMID:32862143]

82. Hishinuma S, Sato Y, Kobayashi Y, Komazaki H and Saito M. (2008) Intact cell binding for in vitro prediction of sedative and non-sedative histamine H1-receptor antagonists based on 
receptor internalization. J Pharmacol Sci 107: 66-79 [PMID:18446005]

83. Hofstra CL, Desai PJ, Thurmond RL and Fung-Leung WP. (2003) Histamine H4 receptor mediates chemotaxis and calcium mobilization of mast cells. J Pharmacol Exp Ther 305: 1212-21 [PMID:12626656]

84. Honrubia MA, Vilaró MT, Palacios JM and Mengod G. (2000) Distribution of the histamine H(2) receptor in monkey brain and its mRNA localization in monkey and human brain. Synapse 38: 343-54 [PMID:11020238]

85. Héron A, Rouleau A, Cochois V, Pillot C, Schwartz JC and Arrang JM. (2001) Expression analysis of the histamine $\mathrm{H}(3)$ receptor in developing rat tissues. Mech Dev 105: 167-73 [PMID:11429293]

86. Inoue I, Taniuchi I, Kitamura D, Jenkins NA, Gilbert DJ, Copeland NG and Watanabe T. (1996) Characteristics of the mouse genomic histamine H1 receptor gene. Genomics 36: 178-81 [PMID:8812432]

87. Inoue I, Yanai K, Kitamura D, Taniuchi I, Kobayashi T, Niimura K, Watanabe $\mathrm{T}$ and Watanabe T. (1996) Impaired locomotor activity and exploratory behavior in mice lacking histamine H1 receptors. Proc Natl Acad Sci USA 93: 13316-20 [PMID:8917588]

88. Ishiwata K, Kawamura K, Wang WF, Tsukada H, Harada N, Mochizuki H, Kimura Y, Ishii K, Iwata R and Yanai K. (2004) Evaluation of in vivo selective binding of [11C]doxepin to histamine H1 receptors in five animal species. Nucl Med Biol 31: 493-502 [PMID:15093820]

89. Izumizaki M, Iwase M, Kimura H, Yanai K, Watanabe T and Homma I. (2000) Lack of temperature-induced polypnea in histamine H1 receptor-deficient mice. Neurosci Lett 284: 13942 [PMID:10773418]

90. Jablonowski JA, Grice CA, Chai W, Dvorak CA, Venable JD, Kwok AK, Ly KS, Wei J, Baker SM and Desai PJ et al.. (2003) The first potent and selective non-imidazole human histamine H4 receptor antagonists. J Med Chem 46: 3957-60 [PMID:12954048]

91. Jansen FP, Mochizuki T, Maeyama K, Leurs R and Timmerman H. (2000) Characterization of histamine H3 receptors in mouse brain using the H3 antagonist [125I]iodophenpropit. Naunyn Schmiedebergs Arch Pharmacol 362: 60-7 [PMID:10935534]

92. Jansen FP, Wu TS, Voss HP, Steinbusch HW, Vollinga RC, Rademaker B, Bast A and Timmerman H. (1994) Characterization of the binding of the first selective radiolabelled histamine H3receptor antagonist, [125I]-iodophenpropit, to rat brain. Br J Pharmacol 113: 355-62 [PMID:7834183]

93. Jansen-Olesen I, Ottosson A, Cantera L, Strunk S, Lassen LH, Olesen J, Mortensen A, Engel U and Edvinsson L. (1997) Role of endothelium and nitric oxide in histamine-induced responses in human cranial arteries and detection of mRNA encoding H1- and H2-receptors by RT-PCR. $\mathrm{Br} J$ Pharmacol 121: 41-48 [PMID:9146885]

94. Janssens F, Leenaerts J, Diels G, De Boeck B, Megens A, Langlois X, van Rossem K, Beetens J and Borgers M. (2005) Norpiperidine imidazoazepines as a new class of potent, selective, and nonsedative H1 antihistamines. J Med Chem 48: 2154-66 [PMID:15771458]

95. Jemima EA, Prema A and Thangam EB. (2014) Functional characterization of histamine H4 receptor on human mast cells. Mol Immunol 62: 19-28 [PMID:24934979]

96. Jin H, Koyama T, Hatanaka Y, Akiyama S, Takayama F and Kawasaki H. (2006) Histamineinduced vasodilation and vasoconstriction in the mesenteric resistance artery of the rat. Eur J Pharmacol 529: 136-44 [PMID:16337938]

97. Kaku S, Isobe Y, Kiuchi Y, Tanaka M, Muramatsu M and Higuchi S. (1999) Interaction of the new histamine H2-receptor antagonist pibutidine hydrochloride with canine cloned H2-receptor expressed cells. Arzneimittelforschung 49: 67-71 [PMID:10028383]

98. Kinnunen A, Lintunen M, Karlstedt K, Fukui H and Panula P. (1998) In situ detection of H1receptor mRNA and absence of apoptosis in the transient histamine system of the embryonic rat brain. J Comp Neurol 394: 127-37 [PMID:9550146]

99. Kitbunnadaj R, Hashimoto T, Poli E, Zuiderveld OP, Menozzi A, Hidaka R, de Esch IJ, Bakker RA, Menge WM and Yamatodani A et al.. (2005) N-substituted piperidinyl alkyl imidazoles: discovery of methimepip as a potent and selective histamine H3 receptor agonist. J Med Chem 48: 2100-7 [PMID:15771452]

100. Kitbunnadaj R, Zuiderveld OP, Christophe B, Hulscher S, Menge WM, Gelens E, Snip E, Bakker RA, Celanire S and Gillard M et al.. (2004) Identification of 4-(1H-imidazol-4(5)ylmethyl)pyridine (immethridine) as a novel, potent, and highly selective histamine $\mathrm{H}(3)$ receptor agonist. J Med Chem 47: 2414-7 [PMID:15115383]

101. Kitbunnadaj R, Zuiderveld OP, De Esch IJ, Vollinga RC, Bakker R, Lutz M, Spek AL, Cavoy E, Deltent MF and Menge WM et al.. (2003) Synthesis and structure-activity relationships of conformationally constrained histamine H(3) receptor agonists. J Med Chem 46: 5445-57 [PMID:14640553]

102. Ko K, Kim HJ, Ho PS, Lee SO, Lee JE, Min CR, Kim YC, Yoon JH, Park EJ and Kwon YJ et al.. (2018) Discovery of a Novel Highly Selective Histamine H4 Receptor Antagonist for the Treatment of Atopic Dermatitis. J Med Chem 61: 2949-2961 [PMID:29579390] 
103. Kobayashi T, Inoue I, Jenkins NA, Gilbert DJ, Copeland NG and Watanabe T. (1996) Cloning, RNA expression, and chromosomal location of a mouse histamine H2 receptor gene. Genomics 37: 390-4 [PMID:8938453]

104. Kobayashi T, Tonai S, Ishihara Y, Koga R, Okabe S and Watanabe T. (2000) Abnormal functional and morphological regulation of the gastric mucosa in histamine $\mathrm{H} 2$ receptor-deficient mice. $J$ Clin Invest 105: 1741-9 [PMID:10862789]

105. Koyama M, Seyedi N, Fung-Leung WP, Lovenberg TW and Levi R. (2003) Norepinephrine release from the ischemic heart is greatly enhanced in mice lacking histamine H3 receptors. Mol Pharmacol 63: 378-82 [PMID:12527809]

106. Kraus A, Ghorai P, Birnkammer T, Schnell D, Elz S, Seifert R, Dove S, Bernhardt G and Buschauer A. (2009) N(G)-acylated aminothiazolylpropylguanidines as potent and selective histamine H(2) receptor agonists. ChemMedChem 4: 232-40 [PMID:19072936]

107. Kroeze WK, Hufeisen SJ, Popadak BA, Renock SM, Steinberg S, Ernsberger P, Jayathilake K, Meltzer HY and Roth BL. (2003) H1-histamine receptor affinity predicts short-term weight gain for typical and atypical antipsychotic drugs. Neuropsychopharmacology 28: 519-26 [PMID:12629531]

108. Kubo N, Shirakawa O, Kuno T and Tanaka C. (1987) Antimuscarinic effects of antihistamines: quantitative evaluation by receptor-binding assay. Jpn J Pharmacol 43: 277-82 [PMID:2884340]

109. Kubota K, Kurebayashi H, Miyachi H, Tobe M, Onishi M and Isobe Y. (2011) Synthesis and structure-activity relationship of tricyclic carboxylic acids as novel anti-histamines. Bioorg Med Chem 19: 3005-21 [PMID:21470866]

110. Kühn B, Schmid A, Harteneck C, Gudermann T and Schultz G. (1996) G proteins of the Gq family couple the H2 histamine receptor to phospholipase C. Mol Endocrinol 10: 1697-1707 [PMID:8961278]

111. Le Coniat M, Traiffort E, Ruat M, Arrang JM and Berger R. (1994) Chromosomal localization of the human histamine H1-receptor gene. Hum Genet 94: 186-8 [PMID:8045566]

112. Leth R, Elander B, Haglund U, Olbe L and Fellenius E. (1987) Histamine H2-receptor of human and rabbit parietal cells. Am J Physiol 253: G497-501 [PMID:3661710]

113. Leurs R, Smit MJ, Menge WM and Timmerman H. (1994) Pharmacological characterization of the human histamine $\mathrm{H} 2$ receptor stably expressed in Chinese hamster ovary cells. $\mathrm{Br} \mathrm{J}$ Pharmacol 112: 847-54 [PMID:7921611]

114. Leurs R, Smit MJ and Timmerman H. (1995) Molecular pharmacological aspects of histamine receptors. Pharmacol Ther 66: 413-63 [PMID:7494855]

115. Lewis TA, Young MA, Arrington MP, Bayless L, Cai X, Collart P, Eckman JB, Ellis JL, Ene DG and Libertine L et al.. (2004) Cetirizine and loratadine-based antihistamines with 5-lipoxygenase inhibitory activity. Bioorg Med Chem Lett 14: 5591-4 [PMID:15482930]

116. Li H, Choe NH, Wright DT and Adler KB. (1995) Histamine provokes turnover of inositol phospholipids in guinea pig and human airway epithelial cells via an H1-receptor/G proteindependent mechanism. Am J Respir Cell Mol Biol 12: 416-24 [PMID:7695921]

117. Ligneau X, Morisset S, Tardivel-Lacombe J, Gbahou F, Ganellin CR, Stark H, Schunack W, Schwartz JC and Arrang JM. (2000) Distinct pharmacology of rat and human histamine H(3) receptors: role of two amino acids in the third transmembrane domain. BrJ Pharmacol 131: 1247-50 [PMID:11090094]

118. Lim HD, Smits RA, Bakker RA, van Dam CM, de Esch IJ and Leurs R. (2006) Discovery of S-(2guanidylethyl)-isothiourea (VUF 8430) as a potent nonimidazole histamine H4 receptor agonist. J Med Chem 49: 6650-1 [PMID:17154494]

119. Lim HD, van Rijn RM, Ling P, Bakker RA, Thurmond RL and Leurs R. (2005) Evaluation of histamine H1-, H2-, and H3-receptor ligands at the human histamine $\mathrm{H} 4$ receptor: identification of 4-methylhistamine as the first potent and selective H4 receptor agonist. J Pharmacol Exp Ther 314: 1310-21 [PMID:15947036]

120. Ling P, Ngo K, Nguyen S, Thurmond RL, Edwards JP, Karlsson L and Fung-Leung WP. (2004) Histamine $\mathrm{H} 4$ receptor mediates eosinophil chemotaxis with cell shape change and adhesion molecule upregulation. Br J Pharmacol 142: 161-71 [PMID:15131002]

121. Lipani L, Odadzic D, Weizel L, Schwed JS, Sadek B and Stark H. (2014) Studies on molecular properties prediction and histamine H3 receptor affinities of novel ligands with uracil-based motifs. Eur J Med Chem 86: 578-88 [PMID:25218907]

122. Lippert U, Artuc M, Grützkau A, Babina M, Guhl S, Haase I, Blaschke V, Zachmann K, Knosalla $\mathrm{M}$ and Middel P et al.. (2004) Human skin mast cells express H2 and H4, but not H3 receptors. J Invest Dermatol 123: 116-23 [PMID:15191551]

123. Liu C, Ma X, Jiang X, Wilson SJ, Hofstra CL, Blevitt J, Pyati J, Li X, Chai W and Carruthers N et al.. (2001) Cloning and pharmacological characterization of a fourth histamine receptor $(\mathrm{H}(4))$ expressed in bone marrow. Mol Pharmacol 59: 420-6 [PMID:11179434]

124. Liu C, Wilson SJ, Kuei C and Lovenberg TW. (2001) Comparison of human, mouse, rat, and guinea pig histamine $\mathrm{H} 4$ receptors reveals substantial pharmacological species variation. $J$ Pharmacol Exp Ther 299: 121-30 [PMID:11561071] 
125. Lo WW and Fan TP. (1987) Histamine stimulates inositol phosphate accumulation via the H1receptor in cultured human endothelial cells. Biochem Biophys Res Commun 148: 47-53 [PMID:3675593]

126. LOEW ER. (1947) Pharmacology of antihistamine compounds. Physiol Rev 27: 542-73 [PMID:20267759]

127. Lovenberg TW, Pyati J, Chang H, Wilson SJ and Erlander MG. (2000) Cloning of rat histamine $\mathrm{H}(3)$ receptor reveals distinct species pharmacological profiles. J Pharmacol Exp Ther 293: 7718 [PMID:10869375]

128. Lovenberg TW, Roland BL, Wilson SJ, Jiang X, Pyati J, Huvar A, Jackson MR and Erlander MG. (1999) Cloning and functional expression of the human histamine H3 receptor. Mol Pharmacol 55: 1101-7 [PMID:10347254]

129. Maconochie JG, Woodings EP and Richards DA. (1979) Effects of H1- and H2-receptor blocking agents on histamine-induced bronchoconstriction in non-asthmatic subjects. Br J Clin Pharmacol 7: 231-6 [PMID:34415]

130. Main IH and Whittle BJ. (1976) A study of the vascular and acid-secretory responses of the rat gastric mucosa to histamine. J Physiol (Lond.) 257: 407-18 [PMID:950600]

131. Malmberg-Aiello P, Lamberti C, Ipponi A, Bartolini A and Schunack W. (1998) Evidence for hypernociception induction following histamine $\mathrm{H1}$ receptor activation in rodents. Life Sci 63 : 463-76 [PMID:9718070]

132. Malmlöf K, Zaragoza F, Golozoubova V, Refsgaard HH, Cremers T, Raun K, Wulff BS, Johansen PB, Westerink B and Rimvall K. (2005) Influence of a selective histamine H3 receptor antagonist on hypothalamic neural activity, food intake and body weight. Int J Obes (Lond.) 29: 1402-12 [PMID:16151415]

133. Markwardt KL, Magnino PE and Pang IH. (1996) Effect of histamine on phosphoinositide turnover and intracellular calcium in human ciliary muscle cells. Exp Eye Res 62: 511-20 [PMID:8759520]

134. Martínez-Mir MI, Estañ L, Morales-Olivas FJ and Rubio E. (1992) Effect of histamine and histamine analogues on human isolated myometrial strips. Br J Pharmacol 107: 528-31 [PMID:1358393]

135. Maruko T, Nakahara T, Sakamoto K, Saito M, Sugimoto N, Takuwa Y and Ishii K. (2005) Involvement of the $\beta \gamma$ subunits of $\mathrm{G}$ proteins in the cAMP response induced by stimulation of the histamine H1 receptor. Naunyn Schmiedebergs Arch Pharmacol 372: 153-9 [PMID:16189696]

136. Masaki T, Chiba S, Tatsukawa H, Noguchi H, Kakuma T, Endo M, Seike M, Watanabe T and Yoshimatsu H. (2005) The role of histamine H1 receptor and H2 receptor in LPS-induced liver injury. FASEB J 19: 1245-52 [PMID:16051691]

137. Masaki T, Chiba S, Yasuda T, Noguchi H, Kakuma T, Watanabe T, Sakata T and Yoshimatsu H. (2004) Involvement of hypothalamic histamine H1 receptor in the regulation of feeding rhythm and obesity. Diabetes 53: 2250-60 [PMID:15331534]

138. Masaki T, Yoshimatsu H, Chiba S, Watanabe T and Sakata T. (2001) Targeted disruption of histamine H1-receptor attenuates regulatory effects of leptin on feeding, adiposity, and UCP family in mice. Diabetes 50: 385-391 [PMID:11272151]

139. Matsubara M, Ohmori K and Hasegawa K. (2006) Histamine H1 receptor-stimulated interleukin 8 and granulocyte macrophage colony-stimulating factor production by bronchial epithelial cells requires extracellular signal-regulated kinase signaling via protein kinase C. Int Arch Allergy Immunol 139: 279-93 [PMID:16491014]

140. Matsuda N, Jesmin S, Takahashi Y, Hatta E, Kobayashi M, Matsuyama K, Kawakami N, Sakuma I, Gando S and Fukui H et al.. (2004) Histamine H1 and H2 receptor gene and protein levels are differentially expressed in the hearts of rodents and humans. J Pharmacol Exp Ther 309: 786-95 [PMID:14752062]

141. McIsaac RL, Johnston BJ and Flannery MC. (1983) Dose-response curve analysis of gastric secretory responses in the dog and man to impromidine: a new histamine-H2-receptor agonist. $J$ Pharmacol Exp Ther 225: 186-90 [PMID:6131998]

142. McIsaac RL, Johnston BJ, Flannery MC and Fielding LP. (1982) Gastric acid secretion induced by impromidine in the dog and man: analysis of dose-response relationships. Agents Actions 12: 166-167 [PMID:6211064]

143. McNeill JH and Verma SC. (1975) Histamine2 receptors in rat uterus. Res Commun Chem Pathol Pharmacol 11: 639-44 [PMID:1179032]

144. Medhurst AD, Atkins AR, Beresford IJ, Brackenborough K, Briggs MA, Calver AR, Cilia J, Cluderay JE, Crook B and Davis JB et al.. (2007) GSK189254, a novel H3 receptor antagonist that binds to histamine $\mathrm{H} 3$ receptors in Alzheimer's disease brain and improves cognitive performance in preclinical models. J Pharmacol Exp Ther 321: 1032-45 [PMID:17327487]

145. Merlos M, Giral M, Balsa D, Ferrando R, Queralt M, Puigdemont A, García-Rafanell J and Forn J. (1997) Rupatadine, a new potent, orally active dual antagonist of histamine and plateletactivating factor (PAF). J Pharmacol Exp Ther 280: 114-21 [PMID:8996188]

146. Migalovich-Sheikhet H, Friedman S, Mankuta D and Levi-Schaffer F. (2012) Novel identified 
receptors on mast cells. Front Immunol 3: 238 [PMID:22876248]

147. Mitsuhashi M, Mitsuhashi T and Payan DG. (1989) Multiple signaling pathways of histamine H2 receptors. Identification of an $\mathrm{H} 2$ receptor-dependent $\mathrm{Ca} 2+$ mobilization pathway in human HL60 promyelocytic leukemia cells. J Biol Chem 264: 18356-62 [PMID:2553705]

148. Mobarakeh JI, Sakurada S, Hayashi T, Orito T, Okuyama K, Sakurada T, Kuramasu A, Watanabe T, Watanabe T and Yanai K. (2002) Enhanced antinociception by intrathecally-administered morphine in histamine H1 receptor gene knockout mice. Neuropharmacology 42: 1079-88 [PMID:12128009]

149. Mobarakeh JI, Sakurada S, Katsuyama S, Kutsuwa M, Kuramasu A, Lin ZY, Watanabe T, Hashimoto Y, Watanabe T and Yanai K. (2000) Role of histamine H(1) receptor in pain perception: a study of the receptor gene knockout mice. Eur J Pharmacol 391: 81-9 [PMID:10720638]

150. Mobarakeh JI, Takahashi K, Sakurada S, Nishino S, Watanabe H, Kato M, Naghdi N and Yanai K. (2005) Enhanced antinociception by intracerebroventricularly administered orexin A in histamine H1 or H2 receptor gene knockout mice. Pain 118: 254-62 [PMID:16202530]

151. Mochizuki H, Kimura Y, Ishii K, Oda K, Sasaki T, Tashiro M, Yanai K and Ishiwata K. (2004) Quantitative measurement of histamine $\mathrm{H}(1)$ receptors in human brains by PET and [11C]doxepin. Nucl Med Biol 31: 165-71 [PMID:15013481]

152. Moguilevsky N, Varsalona F, Noyer M, Gillard M, Guillaume JP, Garcia L, Szpirer C, Szpirer J and Bollen A. (1994) Stable expression of human H1-histamine-receptor cDNA in Chinese hamster ovary cells. Pharmacological characterisation of the protein, tissue distribution of messenger RNA and chromosomal localisation of the gene. Eur J Biochem 224: 489-95 [PMID:7925364]

153. Mollet A, Lutz TA, Meier S, Riediger T, Rushing PA and Scharrer E. (2001) Histamine H1 receptors mediate the anorectic action of the pancreatic hormone amylin. Am J Physiol Regul Integr Comp Physiol 281: R1442-8 [PMID:11641114]

154. Monczor F, Fernandez N, Legnazzi BL, Riveiro ME, Baldi A, Shayo C and Davio C. (2003) Tiotidine, a histamine H2 receptor inverse agonist that binds with high affinity to an inactive Gprotein-coupled form of the receptor. Experimental support for the cubic ternary complex model. Mol Pharmacol 64: 512-20 [PMID:12869657]

155. Morimoto T, Yamamoto Y, Mobarakeh JI, Yanai K, Watanabe T, Watanabe T and Yamatodani A. (1999) Involvement of the histaminergic system in leptin-induced suppression of food intake. Physiol Behav 67: 679-83 [PMID:10604837]

156. Morisset S, Sasse A, Gbahou F, Héron A, Ligneau X, Tardivel-Lacombe J, Schwartz JC and Arrang JM. (2001) The rat H3 receptor: gene organization and multiple isoforms. Biochem Biophys Res Commun 280: 75-80 [PMID:11162480]

157. Morphy R and Rankovic Z. (2005) Designed multiple ligands. An emerging drug discovery paradigm. J Med Chem 48: 6523-43 [PMID:16220969]

158. Morse KL, Behan J, Laz TM, West Jr RE, Greenfeder SA, Anthes JC, Umland S, Wan Y, Hipkin RW and Gonsiorek W et al.. (2001) Cloning and characterization of a novel human histamine receptor. J Pharmacol Exp Ther 296: 1058-66 [PMID:11181941]

159. Morton DM. (1987) Pharmacology and toxicology of nizatidine. Scand J Gastroenterol Suppl 136: 1-8 [PMID:2892249]

160. Myou S, Fujimura M, Nishi K, Ohka T and Matsuda T. (1995) Inhibitory effect of terfenadine, a selective $\mathrm{H} 1$ histamine antagonist, on alcoholic beverage-induced bronchoconstriction in asthmatic patients. Eur Respir J 8: 619-23 [PMID:7545133]

161. Nagase T, Mizutani T, Ishikawa S, Sekino E, Sasaki T, Fujimura T, Ito S, Mitobe Y, Miyamoto Y and Yoshimoto R et al.. (2008) Synthesis, structure-activity relationships, and biological profiles of a quinazolinone class of histamine H3 receptor inverse agonists. J Med Chem 51: 4780-9 [PMID:18598020]

162. Nakahara H, Izushi K, Sugimoto Y, Watanabe T and Kamei C. (2000) Vascular permeability in allergic conjunctivitis in mice lacking histamine $\mathrm{H} 1$ receptors. Eur J Pharmacol 409: 313-7 [PMID:11108826]

163. Nakamura T, Itadani H, Hidaka Y, Ohta M and Tanaka K. (2000) Molecular cloning and characterization of a new human histamine receptor, HH4R. Biochem Biophys Res Commun 279: 615-20 [PMID:11118334]

164. Nakayama T, Kato Y, Hieshima K, Nagakubo D, Kunori Y, Fujisawa T and Yoshie O. (2004) Liverexpressed chemokine/CC chemokine ligand 16 attracts eosinophils by interacting with histamine H4 receptor. J Immunol 173: 2078-83 [PMID:15265943]

165. Nguyen T, Shapiro DA, George SR, Setola V, Lee DK, Cheng R, Rauser L, Lee SP, Lynch KR and Roth BL et al.. (2001) Discovery of a novel member of the histamine receptor family. Mol Pharmacol 59: 427-33 [PMID:11179435]

166. Nirogi R, Shinde A, Mohammed AR, Badange RK, Reballi V, Bandyala TR, Saraf SK, Bojja K, Manchineella S and Achanta PK et al.. (2019) Discovery and Development of N-[4-(1Cyclobutylpiperidin-4-yloxy)phenyl]-2-(morpholin-4-yl)acetamide Dihydrochloride (SUVN- 
G3031): A Novel, Potent, Selective, and Orally Active Histamine $\mathrm{H}_{3}$ Receptor Inverse Agonist with Robust Wake-Promoting Activity. J Med Chem 62: 1203-1217 [PMID:30629436]

167. Nonaka T, Mio M, Doi M and Tasaka K. (1992) Histamine-induced differentiation of HL-60 cells. The role of cAMP and protein kinase A. Biochem Pharmacol 44: 1115-21 [PMID:1329760]

168. O'Reilly M, Alpert R, Jenkinson S, Gladue RP, Foo S, Trim S, Peter B, Trevethick M and Fidock M. (2002) Identification of a histamine H4 receptor on human eosinophils--role in eosinophil chemotaxis. J Recept Signal Transduct Res 22: 431-48 [PMID:12503632]

169. Oda T, Morikawa N, Saito Y, Masuho Y and Matsumoto S. (2000) Molecular cloning and characterization of a novel type of histamine receptor preferentially expressed in leukocytes. $J$ Biol Chem 275: 36781-6 [PMID:10973974]

170. Ogawa T, Maeda K, Tonai S, Kobayashi T, Watanabe T and Okabe S. (2003) Utilization of knockout mice to examine the potential role of gastric histamine H2-receptors in Menetrier's disease. J Pharmacol Sci 91: 61-70 [PMID:12686732]

171. Ohinata K, Shimano T, Yamauchi R, Sakurada S, Yanai K and Yoshikawa M. (2004) The anorectic effect of neurotensin is mediated via a histamine H1 receptor in mice. Peptides 25: 2135-8 [PMID:15572202]

172. Orange PR, Heath PR, Wright SR, Ramchand CN, Kolkeiwicz L and Pearson RC. (1996) Individuals with schizophrenia have an increased incidence of the H2R649G allele for the histamine H2 receptor gene. Mol Psychiatry 1: 466-9 [PMID:9154248]

173. Panula P, Chazot PL, Cowart M, Gutzmer R, Leurs R, Liu WL, Stark H, Thurmond RL and Haas HL. (2015) International Union of Basic and Clinical Pharmacology. XCVIII. Histamine Receptors. Pharmacol Rev 67: 601-55 [PMID:26084539]

174. Parsons ME and Ganellin CR. (2006) Histamine and its receptors. BrJ Pharmacol 147 Suppl 1: S127-35 [PMID:16402096]

175. Passani MB, Cangioli I, Baldi E, Bucherelli C, Mannaioni PF and Blandina P. (2001) Histamine H3 receptor-mediated impairment of contextual fear conditioning and in-vivo inhibition of cholinergic transmission in the rat basolateral amygdala. Eur J Neurosci 14: 1522-32 [PMID:11722614]

176. Pearlstein R, Vaz R and Rampe D. (2003) Understanding the structure-activity relationship of the human ether-a-go-go-related gene cardiac $\mathrm{K}+$ channel. A model for bad behavior. J Med Chem 46: 2017-22 [PMID:12747773]

177. Petersen H and Grossman MI. (1978) Stimulation of gastric acid secretion by dimaprit in unanesthetized rats. Agents Actions 8: 566-567 [PMID:742553]

178. Petremann M, Gueguen C, Delgado Betancourt V, Wersinger E and Dyhrfjeld-Johnsen J. (2020) Effect of the novel histamine $\mathrm{H}_{4}$ receptor antagonist SENS-111 on spontaneous nystagmus in a rat model of acute unilateral vestibular loss. Br J Pharmacol 177: 623-633 [PMID:31347148]

179. Pillot C, Heron A, Cochois V, Tardivel-Lacombe J, Ligneau X, Schwartz JC and Arrang JM. (2002) A detailed mapping of the histamine $\mathrm{H}(3)$ receptor and its gene transcripts in rat brain. Neuroscience 114: 173-93 [PMID:12207964]

180. Procopiou PA, Browning C, Buckley JM, Clark KL, Fechner L, Gore PM, Hancock AP, Hodgson ST, Holmes DS and Kranz M et al.. (2011) The discovery of phthalazinone-based human H1 and H3 single-ligand antagonists suitable for intranasal administration for the treatment of allergic rhinitis. J Med Chem 54: 2183-95 [PMID:21381763]

181. Ratnala VR, Swarts HG, VanOostrum J, Leurs R, DeGroot HJ, Bakker RA and DeGrip WJ. (2004) Large-scale overproduction, functional purification and ligand affinities of the His-tagged human histamine H1 receptor. Eur J Biochem 271: 2636-46 [PMID:15206929]

182. Riddy DM, Cook AE, Diepenhorst NA, Bosnyak S, Brady R, Mannoury la Cour C, Mocaer E, Summers RJ, Charman WN and Sexton PM et al.. (2017) Isoform-Specific Biased Agonism of Histamine H3 Receptor Agonists. Mol Pharmacol 91: 87-99 [PMID:27864425]

183. Rizk A, Curley J, Robertson J and Raber J. (2004) Anxiety and cognition in histamine H3 receptor-/- mice. Eur J Neurosci 19: 1992-6 [PMID:15078574]

184. Roche O, Nettekoven M, Vifian W and Sarmiento RM. (2008) Refinement of histamine H3 ligands pharmacophore model leads to a new class of potent and selective naphthalene inverse agonists. Bioorg Med Chem Lett 18: 4377-9 [PMID:18606542]

185. Rouleau A, Héron A, Cochois V, Pillot C, Schwartz JC and Arrang JM. (2004) Cloning and expression of the mouse histamine H3 receptor: evidence for multiple isoforms. J Neurochem 90: 1331-8 [PMID:15341517]

186. Ruat M, Traiffort E, Arrang JM, Leurs R and Schwartz JC. (1991) Cloning and tissue expression of a rat histamine H2-receptor gene. Biochem Biophys Res Commun 179: 1470-8 [PMID:1930188]

187. Saitoh T, Fukushima Y, Otsuka H, Ishikawa M, Tamai M, Takahashi H, Mori H, Asano T, Anai M and Ishikawa $\mathrm{T}$ et al.. (2002) Effects of N-alpha-methyl-histamine on human $\mathrm{H}(2)$ receptors expressed in CHO cells. Gut 50: 786-9 [PMID:12010879]

188. Sander LE, Lorentz A, Sellge G, Coëffier M, Neipp M, Veres T, Frieling T, Meier PN, Manns MP and Bischoff SC. (2006) Selective expression of histamine receptors H1R, H2R, and H4R, but 
not H3R, in the human intestinal tract. Gut 55: 498-504 [PMID:16299042]

189. Savall BM, Chavez F, Tays K, Dunford PJ, Cowden JM, Hack MD, Wolin RL, Thurmond RL and Edwards JP. (2014) Discovery and SAR of 6-alkyl-2,4-diaminopyrimidines as histamine $\mathrm{H}_{4}$ receptor antagonists. J Med Chem 57: 2429-39 [PMID:24495018]

190. Schellenberg RR, Duff MJ, Foster A and Paddon HB. (1986) Histamine releases PGI2 from human pulmonary artery. Prostaglandins 32: 201-9 [PMID:3541061]

191. Schotte A, Janssen PF, Gommeren W, Luyten WH, Van Gompel P, Lesage AS, De Loore K and Leysen JE. (1996) Risperidone compared with new and reference antipsychotic drugs: in vitro and in vivo receptor binding. Psychopharmacology (Berl.) 124: 57-73 [PMID:8935801]

192. Schwartz J-C, Arrang JM, Garbarg M, Pollard H and Ruat M. (1991) Histaminergic transmission in the mammalian brain. Physiol Rev 71: 1-51 [PMID:1846044]

193. Segawa K, Nakazawa S, Naito Y, Imai K, Kachi T, Tsukamoto S, Kajikawa M, Aichi M, Kimoto E and Sano H et al.. (1979) An experimental study on histamine H2-receptor antagonist on calcium, gastrin and histamine induced gastric acid secretion in rat. Gastroenterol Jpn 14: 53944 [PMID:527795]

194. Seifert R, Wenzel-Seifert K, Burckstummer T, Pertz HH, Schunack W, Dove S, Buschauer A and Elz S. (2003) Multiple differences in agonist and antagonist pharmacology between human and guinea pig histamine H1-receptor. J Pharmacol Exp Ther 305: 1104-15 [PMID:12626648]

195. Shimamura T, Shiroishi M, Weyand S, Tsujimoto H, Winter G, Katritch V, Abagyan R, Cherezov V, Liu W and Han GW et al.. (2011) Structure of the human histamine H1 receptor complex with doxepin. Nature 475: 65-70 [PMID:21697825]

196. Shin N, Coates E, Murgolo NJ, Morse KL, Bayne M, Strader CD and Monsma Jr FJ. (2002) Molecular modeling and site-specific mutagenesis of the histamine-binding site of the histamine H4 receptor. Mol Pharmacol 62: 38-47 [PMID:12065753]

197. Smit MJ, Leurs R, Alewijnse AE, Blauw J, Van Nieuw Amerongen GP, Van De Vrede Y, Roovers E and Timmerman H. (1996) Inverse agonism of histamine H2 antagonist accounts for upregulation of spontaneously active histamine H2 receptors. Proc Natl Acad Sci USA 93: 68027 [PMID:8692899]

198. Smits RA, Lim HD, Stegink B, Bakker RA, de Esch IJ and Leurs R. (2006) Characterization of the histamine $\mathrm{H} 4$ receptor binding site. Part 1 . Synthesis and pharmacological evaluation of dibenzodiazepine derivatives. J Med Chem 49: 4512-6 [PMID:16854056]

199. Sonobe Y, Nakane H, Watanabe T and Nakano K. (2004) Regulation of Con A-dependent cytokine production from CD4+ and CD8+ T lymphocytes by autosecretion of histamine. Inflamm Res 53: 87-92 [PMID:15021962]

200. Spitaler MM, Hammer A, Malli R and Graier WF. (2002) Functional analysis of histamine receptor subtypes involved in endothelium-mediated relaxation of the human uterine artery. Clin Exp Pharmacol Physiol 29: 711-6 [PMID:12100006]

201. Sánchez C and Hyttel J. (1999) Comparison of the effects of antidepressants and their metabolites on reuptake of biogenic amines and on receptor binding. Cell Mol Neurobiol 19: 467-89 [PMID:10379421]

202. Takahashi K, Suwa H, Ishikawa T and Kotani H. (2002) Targeted disruption of H3 receptors results in changes in brain histamine tone leading to an obese phenotype. J Clin Invest 110: 1791-9 [PMID:12488429]

203. Takeshita K, Bacon KB and Gantner F. (2004) Critical role of L-selectin and histamine H4 receptor in zymosan-induced neutrophil recruitment from the bone marrow: comparison with carrageenan. J Pharmacol Exp Ther 310: 272-80 [PMID:14996947]

204. Terzioglu N, van Rijn RM, Bakker RA, De Esch IJ and Leurs R. (2004) Synthesis and structureactivity relationships of indole and benzimidazole piperazines as histamine $\mathrm{H}(4)$ receptor antagonists. Bioorg Med Chem Lett 14: 5251-6 [PMID:15454206]

205. Thomson NC and Kerr JW. (1980) Effect of inhaled H1 and H2 receptor antagonist in normal and asthmatic subjects. Thorax 35: 428-34 [PMID:6449094]

206. Threlfell S, Cragg SJ, Kalló I, Turi GF, Coen CW and Greenfield SA. (2004) Histamine H3 receptors inhibit serotonin release in substantia nigra pars reticulata. J Neurosci 24: 8704-10 [PMID:15470136]

207. Thurmond RL. (2015) The histamine H4 receptor: from orphan to the clinic. Front Pharmacol 6 : 65 [PMID:25873897]

208. Thurmond RL, Desai PJ, Dunford PJ, Fung-Leung WP, Hofstra CL, Jiang W, Nguyen S, Riley JP, Sun S, Williams KN, Edwards JP and Karlsson L. (2004) A potent and selective histamine H4 receptor antagonist with anti-inflammatory properties. J Pharmacol Exp Ther 309: 404-413 [PMID:14722321]

209. Tilly BC, Tertoolen LG, Lambrechts AC, Remorie R, de Laat SW and Moolenaar WH. (1990) Histamine-H1-receptor-mediated phosphoinositide hydrolysis, Ca2 + signalling and membranepotential oscillations in human HeLa carcinoma cells. Biochem J 266: 235-43 [PMID:2155607]

210. Todorov S and Zamfirova R. (1986) The role of H1- and H2-receptors in the modulatory effects of histaminergic agents on adrenergic neurotransmission in rat vas deferens. Methods Find Exp 
Clin Pharmacol 8: 705-9 [PMID:3027468]

211. Tokita S, Takahashi K and Kotani H. (2006) Recent advances in molecular pharmacology of the histamine systems: physiology and pharmacology of histamine H3 receptor: roles in feeding regulation and therapeutic potential for metabolic disorders. J Pharmacol Sci 101: 12-8 [PMID:16648667]

212. Toyota H, Dugovic C, Koehl M, Laposky AD, Weber C, Ngo K, Wu Y, Lee DH, Yanai K and Sakurai E et al.. (2002) Behavioral characterization of mice lacking histamine H(3) receptors. Mol Pharmacol 62: 389-97 [PMID:12130692]

213. Traiffort E, Vizuete ML, Tardivel-Lacombe J, Souil E, Schwartz JC and Ruat M. (1995) The guinea pig histamine $\mathrm{H} 2$ receptor: gene cloning, tissue expression and chromosomal localization of its human counterpart. Biochem Biophys Res Commun 211: 570-7 [PMID:7794271]

214. van Rijn RM, Chazot PL, Shenton FC, Sansuk K, Bakker RA and Leurs R. (2006) Oligomerization of recombinant and endogenously expressed human histamine H(4) receptors. Mol Pharmacol 70: 604-15 [PMID:16645125]

215. Varty LM, Gustafson E, Laverty M and Hey JA. (2004) Activation of histamine H3 receptors in human nasal mucosa inhibits sympathetic vasoconstriction. Eur J Pharmacol 484: 83-9 [PMID:14729385]

216. Venail F, Attali P, Wersinger E, Gomeni R, Poli S and Schmerber S. (2018) Safety, tolerability, pharmacokinetics and pharmacokinetic-pharmacodynamic modelling of the novel $\mathrm{H}_{4}$ receptor inhibitor SENS-111 using a modified caloric test in healthy subjects. Br J Clin Pharmacol 84: 2836-2848 [PMID:30152527]

217. Wager TT, Pettersen BA, Schmidt AW, Spracklin DK, Mente S, Butler TW, Howard H, Lettiere DJ, Rubitski DM and Wong DF et al.. (2011) Discovery of two clinical histamine H(3) receptor antagonists: trans-N-ethyl-3-fluoro-3-[3-fluoro-4-

(pyrrolidinylmethyl)phenyl]cyclobutanecarboxamide (PF-03654746) and trans-3-fluoro-3-[3fluoro-4-(pyrrolidin-1-ylmethyl)phenyl]-N-(2-methylpropyl)cyclobutanecarboxamide (PF03654764). J Med Chem 54: 7602-20 [PMID:21928839]

218. Werfel T, Layton G, Yeadon M, Whitlock L, Osterloh I, Jimenez P, Liu W, Lynch V, Asher A and Tsianakas A et al.. (2019) Efficacy and safety of the histamine $\mathrm{H}_{4}$ receptor antagonist ZPL3893787 in patients with atopic dermatitis. J Allergy Clin Immunol 143: 1830-1837.e4 [PMID:30414855]

219. Whyment AD, Blanks AM, Lee K, Renaud LP and Spanswick D. (2006) Histamine excites neonatal rat sympathetic preganglionic neurons in vitro via activation of $\mathrm{H1}$ receptors. $J$ Neurophysiol 95: 2492-2500 [PMID:16354729]

220. Wieland K, Bongers G, Yamamoto Y, Hashimoto T, Yamatodani A, Menge WM, Timmerman H, Lovenberg TW and Leurs R. (2001) Constitutive activity of histamine h(3) receptors stably expressed in SK-N-MC cells: display of agonism and inverse agonism by $\mathrm{H}(3)$ antagonists. $J$ Pharmacol Exp Ther 299: 908-14 [PMID:11714875]

221. Wong BJ, Wilkins BW and Minson CT. (2004) H1 but not H2 histamine receptor activation contributes to the rise in skin blood flow during whole body heating in humans. J Physiol 560: 941-948 [PMID:15375193]

222. Wulff BS, Hastrup S and Rimvall K. (2002) Characteristics of recombinantly expressed rat and human histamine H3 receptors. Eur J Pharmacol 453: 33-41 [PMID:12393057]

223. Xie SX, Ghorai P, Ye QZ, Buschauer A and Seifert R. (2006) Probing ligand-specific histamine H1- and H2-receptor conformations with NG-acylated Imidazolylpropylguanidines. J Pharmacol Exp Ther 317: 139-46 [PMID:16394198]

224. Yanai K, Son LZ, Endou M, Sakurai E, Nakagawasai O, Tadano T, Kisara K, Inoue I, Watanabe T and Watanabe T. (1998) Behavioural characterization and amounts of brain monoamines and their metabolites in mice lacking histamine H1 receptors. Neuroscience 87: 479-87 [PMID:9740406]

225. Yanai K, Son LZ, Endou M, Sakurai E and Watanabe T. (1998) Targeting disruption of histamine H1 receptors in mice: behavioral and neurochemical characterization. Life Sci 62: 1607-10 [PMID:9585144]

226. Yanovsky Y and Haas HL. (1998) Histamine increases the bursting activity of pyramidal cells in the CA3 region of mouse hippocampus. Neurosci Lett 240: 110-112 [PMID:9486484]

227. Yokotani K, Murakami Y, Okada S, Wang M and Nakamura K. (2000) Histamine H(3) receptormediated inhibition of endogenous acetylcholine release from the isolated, vascularly perfused rat stomach. Eur J Pharmacol 392: 23-9 [PMID:10748268]

228. Zampeli E and Tiligada E. (2009) The role of histamine H4 receptor in immune and inflammatory disorders. Br J Pharmacol 157: 24-33 [PMID:19309354]

229. Zhou FW, Xu JJ, Zhao Y, LeDoux MS and Zhou FM. (2006) Opposite functions of histamine H1 and $\mathrm{H} 2$ receptors and H3 receptor in substantia nigra pars reticulata. J Neurophysiol 96: 158191 [PMID:16738217]

230. Zhu Y, Michalovich D, Wu H, Tan KB, Dytko GM, Mannan IJ, Boyce R, Alston J, Tierney LA and Li X et al.. (2001) Cloning, expression, and pharmacological characterization of a novel human 
histamine receptor. Mol Pharmacol 59: 434-41 [PMID:11179436]

231. Łazewska D, Kuder K, Ligneau X, Camelin JC, Schunack W, Stark H and Kieć-Kononowicz K. (2009) Diether derivatives of homo- or substituted piperidines as non-imidazole histamine H3 receptor ligands. Bioorg Med Chem 17: 3037-42 [PMID:19329325] 